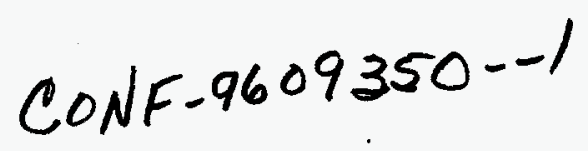

For submission to:

Applied Radiation and Isotopes

Version 3/28/97

\title{
Generator-produced Alpha-emitters
}

\author{
Saed Mirzadeh \\ Nuclear Medicine Group \\ Life Sciences Research Division \\ Oak Ridge National Laboratory (ORNL), \\ Oak Ridge, TN 37831-6229
}

CIRMS Medical Subcommittee
Workshop on Radionuclides Used in Bone Pain Palliation Therapy
NIST, Gaithersburg, Washington
September 27, 1996

This review briefly describes the nuclear characteristics and production parameters for $7.2-\mathrm{h}{ }^{211} \mathrm{At}, 60.6-\mathrm{min}{ }^{212} \mathrm{Bi}$, 45.6-min ${ }^{213} \mathrm{Bi}, 11-d^{233} \mathrm{Ra}$, and $20-h^{255} \mathrm{Fm}$. These $a$-emitting radioisotopes are the subject of current interest for $\alpha$-particle-mediated radioimmunotherapy.

\section{Introduction}

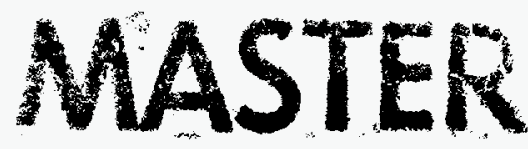

Alpha particles are of considerable interest for radioimmunotherapy applications. Due to their short range in tissue (a few cell diameters), and high linear-energy-transfer (LET), $a$-particles are especially suited for targeting micrometatases and single tumor cells such as leukemia and other blood-borne diseases (Bloomer et al., 1984, Ruegg, et al., 1990, Huneke, et al., 1992, Junghans, et al., 1993, Hartmann, et al., 1994, Kennel and Mirzadeh, 1997, Scheinberg, 1997). The list of potential radionuclides for these applications includes only five $a$-emitting radioisotopes, namely ${ }^{211} \mathrm{At}\left(\mathrm{t}_{1 / 2}=7.2 \mathrm{~h}\right),{ }^{212} \mathrm{Bi}\left(\mathrm{t}_{1 / 2}=60.6 \mathrm{~m}\right),{ }^{213} \mathrm{Bi}\left(\mathrm{t}_{1 / 2}=45.6 \mathrm{~m}\right),{ }^{233} \mathrm{Ra}\left(\mathrm{t}_{1 / 2}=11 \mathrm{~d}\right)$, and ${ }^{255} \mathrm{Fm}\left(\mathrm{t}_{1 / 2}\right.$ $=20 \mathrm{~h}$ ). A list of the generator-produced $a$-emitters and the corresponding references are given in 


\section{DISCLAMMER}

Portions of this document may be illegible in electronic image products. Images are produced from the best available original document. 
Table 1. The nuclear decay characteristics of ${ }^{211} \mathrm{At}^{212} \mathrm{Bi}^{213}{ }^{21}{ }^{233} \mathrm{Ra}$ and ${ }^{255} \mathrm{Fm}$ are summarized in Table 2. The very short half lives of ${ }^{212} \mathrm{Bi}$ and ${ }^{213} \mathrm{Bi}$ limit the use of these radioisotopes to situations in which targeting is rapid, such as in leukemia (Scheinberg, D. A. et al., 1997). Most recently, applications with vascular targeting antibodies for the treatment of lung cancer have also been reported (Kennel and Mirzadeh, 1997).

${ }^{211} \mathrm{Rn}(14.6 \mathrm{~h}) \rightarrow{ }^{211} \mathrm{At}(7.2 \mathrm{~h}) . \quad$ Astatine-211 can be produced through the decay of $14.6 \mathrm{~h}$ ${ }^{211} \mathrm{Rn}$. The ${ }^{211} \mathrm{Rn}$, in turn, is produced through a number of nuclear reactions which are summarized in Table 3. The corresponding references are also given in this table. These reactions include spallation of Th with high energy protons having a cross-section of $0.7 \mathrm{mb}$ at $28 \mathrm{GeV}$ protons or by photo-spallation of Th with a cross-section of $0.13 \mathrm{mb}$ at a photon energy of $300 \mathrm{MeV}$. The production of ${ }^{211} \mathrm{Rn}$ by the ${ }^{209} \mathrm{Bi}\left[{ }^{6} \mathrm{Li}, 4 \mathrm{n}\right]{ }^{211} \mathrm{Rn}$ reaction, with a $\sigma_{\max }=0.7 \mathrm{~b}$ at $\mathrm{E}_{\mathrm{Lj}}=54 \mathrm{MeV}$ and yield of $\sim 2 \mu \mathrm{Ci} / \mathrm{nA}$ at $1 / 2$ saturation, has also been reported. By far, the predominant nuclear reaction for the production of ${ }^{211} \mathrm{At}$, however, is not through a generator system but by direct activation of ${ }^{209} \mathrm{Bi}$ with $28 \mathrm{MeV} a$ particles. The maximum of the excitation function for this reaction is $\sim 1 \mathrm{~b}$ at $\mathrm{E}_{a}=29$ $\mathrm{MeV}$. In order to minimize the production of radiocontaminant ${ }^{210} \mathrm{Po}$, the $\alpha$-particle should exit the Bi target at $E_{a}=20 \mathrm{MeV}$, limiting the Bi thickness to only $100 \mu \mathrm{g} . \mathrm{cm}^{-2}$. The typical yield is $\sim 1.5$ $\mathrm{mCi} / \mu \mathrm{A}$ at half saturation ( $\sim 3.5$ hours of irradiation). Since there are only a few cyclotrons in the U.S. capable of accelerating a-particles to $\sim 28 \mathrm{MeV}$, the required energy for the production of ${ }^{211} \mathrm{At}$ via the ${ }^{209} \mathrm{Bi}[a, 2 \mathrm{n}]$ reaction, the availability of ${ }^{211} \mathrm{At}$ is also very limited. There are a number of procedures reported for extracting ${ }^{211} \mathrm{At}$ from an irradiated $\mathrm{Bi}$ target, and a recent review of the subject is available (Ruth et al, 1988). The dry distillation method is the most convenient approach and it has been described in detail elsewhere (Lambrecht and Mirzadeh, 1985).

${ }^{224} \mathrm{Ra}(3.7 \mathrm{~d}) \rightarrow{ }^{212} \mathrm{~Pb}(10.6 \mathrm{~h}) \rightarrow{ }^{212} \mathrm{Bi}(60.6 \mathrm{~min})$. Bismuth-212 is available from the ${ }^{224} \mathrm{Ra} /{ }^{212} \mathrm{Bi}$ generator system, where ${ }^{224} \mathrm{Ra}$ is the daughter of $1.9-\mathrm{y}^{228} \mathrm{Th}$. Th-228 is the second member of the ${ }^{232} \mathrm{Th}$ decay chain and it is also the decay product of ${ }^{232} \mathrm{U}$ (Fig. 1a). Ra-228 $\left(t_{1 / 2}=5.8 \mathrm{y}\right.$ ) can be extracted from ${ }^{232} \mathrm{Th}$, purified, then allowed to decay to ${ }^{228} \mathrm{Th}$. Each ton of 30 -year old ${ }^{232} \mathrm{Th}$ yields $\sim 100 \mathrm{mCi}$ of ${ }^{228} \mathrm{Ra}$. Th-228, however, can be produced from successive neutron capture and $B^{-}$ decay of ${ }^{226} \mathrm{Ra}$ (Fig.2). This irradiation has been demonstrated in the past to be feasible. However, additional process development is needed to determine production yields and cost. Figure 3 depicts the theoretical production yields of both ${ }^{228} \mathrm{Th}$ and ${ }^{229} \mathrm{Th}$ at the ORNL. High Flux Isotope Reactor 
(HFIR) as a function of irradiation time at a neutron flux of $1 \times 10^{15} \mathrm{n} \cdot \mathrm{s}^{-1} \cdot \mathrm{cm}^{-2}$. For one cycle irradiation ( $\sim 24$ days), the yield of ${ }^{228} \mathrm{Th}$ is $\sim 45 \mathrm{mg}$ (37 Ci) per gram of ${ }^{226} \mathrm{Ra}$. The major drawback for the use of ${ }^{212} \mathrm{Bi}$ is the emission of relatively intense and very high energy $y$-rays (2.6 MeV, 38\%). In the current generator system, ${ }^{224} \mathrm{Ra}$ separated from ${ }^{228} \mathrm{Th}$ is adsorbed on an organic cation exchange resin (highly cross-linked MP-50, $-300 \mu \mathrm{L}$ in volume), and the ${ }^{212} \mathrm{~Pb}$ and ${ }^{212} \mathrm{Bi}$ mixture is eluted with a few $\mathrm{mL}$ of $2 \mathrm{M} \mathrm{HCl}$ or $0.5 \mathrm{M} \mathrm{HI}$ with $\sim 70 \%$ yield and parent breakthrough of

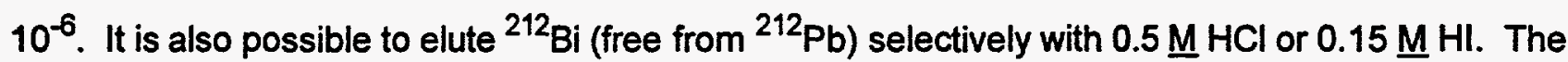
${ }^{224} \mathrm{Ra} /{ }^{212} \mathrm{~Pb} /{ }^{212} \mathrm{Bi}$ generator has a shelf-life of about two weeks, and $10-\mathrm{mCi}$ generators are routinely available from Argonne National Laboratory (ANL).

Unfortunately, radiolytic effects limit the scale of the current organic resin-based ${ }^{224} \mathrm{Ra} \rightarrow{ }^{212} \mathrm{~Pb} \rightarrow{ }^{212} \mathrm{Bi}$ generator to levels insufficient for clinical use. Evaporation (emanation)-based generator systems were developed to overcome this problem (Hursh and Lovaas, 1967, Norman et al., 1991, and Hassfjell and Hoff 1994). At a 1-mCi activity level, the fraction of ${ }^{212} \mathrm{~Pb}$ recovered was decreased from $50 \%$ to $10 \%$ over a one-year period. No absolute values were given for the breakthrough of the Th, but it was stated that Th was not detected in the final solution (Hassfjell and Hoff 1994).

${ }^{225} \mathrm{AC}(10.0 \mathrm{~d}) \rightarrow{ }^{213} \mathrm{Bi}(45.6 \mathrm{~min})$. Among the potential candidates, ${ }^{213} \mathrm{Bi}$ is well suited to clinical applications as ${ }^{213} \mathrm{Bi}$ labeled monoclonal antibody (MAb) and has recently entered phase 1 of human trial against leukemia (Sheinberg, 1997). MAb targeting ${ }^{213} \mathrm{Bi}$ to lung vasculature has also been successful in the therapy of lung tumors in mice (Kennel and Mirzadeh, 1997). Bismuth-213 decays with a $t_{1 / 2}$ of $45.6 \mathrm{~min}$ and emits an $8.4 \mathrm{MeV} a$-particle $97.8 \%$ of the time. The decay of ${ }^{213} \mathrm{Bi}$ follows with the emission of rather low intensity $y$-rays; $440 \mathrm{keV}(26 \%)$ and $1566 \mathrm{keV}(2 \%)$. Similar to the ${ }^{224} \mathrm{Ra} \rightarrow{ }^{212} \mathrm{Bi}$ pathway, carrier-free ${ }^{213} \mathrm{Bi}$ is available from the ${ }^{225} \mathrm{Ac} /{ }^{213} \mathrm{Bi}$ generator system with ${ }^{225} \mathrm{Ac}\left(\mathrm{t}_{1 / 2}=10 \mathrm{~d}\right)$ being the $B^{-}$-decay daughter of $14.8-\mathrm{d}{ }^{225} \mathrm{Ra}$. Ra-225 is the daughter of $7340-y{ }^{229}$ Th which, in turn, is the decay daughter of long-lived ${ }^{233} \mathrm{U}$, Fig. 1b. A unique aspect of ${ }^{233} U$ is its availability at the National Repository of ${ }^{233} U$ which is located at ORNL. U-233 was produced at ORNL in 1960's and 1970's as part of a molten salt breeder reactor program. Currently, the ${ }^{233} \mathrm{U}$ is in long-term storage with no immediate or anticipated need. It is estimated that from ${ }^{233} \mathrm{U}$ stockpile, $\sim 12 \mathrm{~g}(\sim 2.5 \mathrm{Ci})$ of ${ }^{229} \mathrm{Th}$ can be extracted.

Th-228 can also be produced from neutron transmutation of a ${ }^{226} \mathrm{Ra}$ target (Fig. 2). The yield of ${ }^{229} \mathrm{Th}$ is on the order of $7 \mathrm{mg}(\sim 150 \mathrm{mCi})$ per $\mathrm{g}$ of ${ }^{226} \mathrm{Ra}$ for 24 days irradiation at a neutron 
flux of $1 \times 10^{15} \mathrm{n} \cdot \mathrm{s}^{-1} \cdot \mathrm{cm}^{-2}$, with a thermal to epithermal ratio of 10 (Fig. 3). Note that under these conditions, the mass of the contaminant ${ }^{228} \mathrm{Th}$ produced is $\sim 4$ times larger than that of ${ }^{229} \mathrm{Th}$ (the activity ratio is 250). Nevertheless, high purity ${ }^{225} \mathrm{Ac}$ can be obtained from the mixture by initially extracting $\mathrm{Ra}$ from $\mathrm{Th}$ and allowing the $3.7-\mathrm{d}{ }^{224} \mathrm{Ra}$ to decay (10-15 days) then extracting ${ }^{225} \mathrm{AC}$ from the Ra mixture. Note that the ${ }^{224} \mathrm{Ra} a$-decays to ${ }^{220} \mathrm{Rn}$ with no $B^{-}$-decay to ${ }^{224} \mathrm{Ac}$.

It is also possible to produce ${ }^{225} \mathrm{Ac}$ from proton and deuteron irradiation of ${ }^{226} \mathrm{Ra},[p, 2 \mathrm{n}]$ and $[d, n]$ reactions (see Fig. 2). The author is not aware of any reported excitation functions for these reactions.

Although ${ }^{233} \mathrm{U}$ is the only viable source for high purity ${ }^{229} \mathrm{Th}$, the anticipated difficulty with ${ }^{233} \mathrm{U}$ safeguards led us to look at the possibility of extracting Th from pre-existing processing waste of ${ }^{233} \mathrm{U}$. After extensive purification, $\sim 65 \mathrm{mCi}$ of low specific activity $(\sim 0.4 \%){ }^{229} \mathrm{Th}$ has been recovered and $20 \mathrm{mCi}$ of ${ }^{225} \mathrm{Ac}$ is available for sale through the ORNL Isotope Distribution Office on a bi-weekly schedule.

The chemistry of the ${ }^{225} \mathrm{Ac} /{ }^{213} \mathrm{Bi}$ generator is also similar to that described for the ${ }^{212} \mathrm{Bi}$ generator. However, the lower cross-linked resin was found to be more suitable for rapid elution of ${ }^{213} \mathrm{Bi}$ from the generator with ${ }^{225} \mathrm{Ac}$ breakthrough of $<1 \%$. A summary of the ${ }^{213} \mathrm{Bi}$ yield and ${ }^{225} \mathrm{AC}$ and ${ }^{225} \mathrm{Ra}$ breakthrough values are given in Table 4 (Boll and Mirzadeh, 1997). As indicated in the last column, the breakthrough of $R a$ in AG $50 W \times 4$ resin was substantially higher than Ac breakthrough. Thus it follows that in order to reduce the potential contamination of ${ }^{213} \mathrm{Bi}$ with $\mathrm{Ra}$, the Ac generator-load solution should contain a low fraction of Ra. At the 2-3 $\mathrm{mCi}$ level, the radiolytic degradation of organic resin limits the useful shelf-life of a generator to about one week.

${ }^{227} \mathrm{Th}(18.7 \mathrm{~d}) \rightarrow{ }^{223} \mathrm{Ra}(11.4 \mathrm{~d}) . \quad$ The ${ }^{227} \mathrm{Th} /{ }^{223} \mathrm{Ra}$ system is a part of the actinium series and ${ }^{227} \mathrm{Th}$ is produced from $\mathrm{B}^{-}$of $21-\mathrm{y}{ }^{227} \mathrm{Ac}$. The ${ }^{227} \mathrm{Ac}$ can be extracted from ${ }^{235} \mathrm{U}$ or it can be produced by irradiation of ${ }^{226} \mathrm{Ra}$ target in a reactor by the ${ }^{226} \mathrm{Ra}[\mathrm{n}, \mathrm{y}]{ }^{227} \mathrm{Ra}\left(\mathrm{B}^{-}, 42 \mathrm{~min}\right) \rightarrow{ }^{227} \mathrm{AC}$ reaction (Fig. 2). The irradiation route has high yield and eliminates the problem associated with the ${ }^{235} \mathrm{U}$ safeguards (Fig. 3). There are, however, two major difficulties with ${ }^{223} \mathrm{Ra}$. The first is the lack of suitable chelating molecule for attachment of ${ }^{233} \mathrm{Ra}$ to monoclonal antibodies. The second concern is with the decay characteristic of this isotope. As indicated in Table 2, the third decay product of ${ }^{233} \mathrm{Ra}$ is the ${ }^{211} \mathrm{~Pb}$ which has a half-life of 36 minutes. The kinetic energy imparted to ${ }^{211} \mathrm{~Pb}$ due to a-emission ejects the ${ }^{211} \mathrm{~Pb}$ atom from the original carrier molecule and leaves the ${ }^{211} \mathrm{~Pb}$ atom highly charged and reactive (Mirzadeh, 1993). A portion of unbound ${ }^{211} \mathrm{~Pb}$, having 
sufficient time to re-enter the blood stream, results in a substantial dose to the non-targeted tissues. Note that ${ }^{219} \mathrm{~Pb}$ is a highly potent $a$-emitter as well (see Fig. 1c).

${ }^{255} \mathrm{Es}(40 \mathrm{~d}) \rightarrow{ }^{255} \mathrm{Fm}(20.1 \mathrm{~h})$. Among the potential candidates, ${ }^{255} \mathrm{Fm}$ (the daughter of $40-\mathrm{d}$ ${ }^{255}$ Es, a transuranium radioisotope) has the most convenient half-life, but it is doubtful that useful quantities of this radioisotope will be made available within the foreseeable future.

In summary, methods have been demonstrated for large scale production of $a$-emitters for medical applications with the exception of ${ }^{255} \mathrm{Fm}$. Over the next few years, it is expected that clinical generators for in-house production of the short-lived ${ }^{212} \mathrm{Bi}$ and ${ }^{213} \mathrm{Bi}$ will be made available.

Acknowledgements. Research was supported by ORNL Laboratory Directed Research and Development, under the auspices of the U.S. DOE contract DE-AC05-960R22464 with Lockheed Martin Energy Research Corporation.

\section{DISCLAIMER}

This report was prepared as an account of work sponsored by an agency of the United States Government. Neither the United States Government nor any agency thereof, nor any of their employees, makes any warranty, express or implied, or assumes any legal liability or responsibility for the accuracy, completeness, or usefulness of any information, apparatus, product, or process disclosed, or represents that its use would not infringe privately owned rights. Reference herein to any specific commercial product, process, or service by trade name, trademark, manufacturer, or otherwise does not necessarily constitute or imply its endorsement, recommendation, or favoring by the United States Government or any agency thereof. The views and opinions of authors expressed herein do not necessarily state or reflect those of the United States Government or any agency thereof. 


\section{References.}

Atcher R. W., Hines, J. J. and Friedman, A. M., "A Remote System for the Separation of ${ }^{228}$ Th and ${ }^{224}$ Ra," J. Radioanal. Nucl. Chem., Letter, 117, 155 (1987).

Bloomer, W. D., W. H. McLaughlin, R. M. Lambrecht, R. W. Atcher, S. Mirzadeh, J. L. Madara, R. A. Milius, M. R. Zalutsky, S. J. Adelstein, and A. P. Wolf, (1984) "At-211 Radiocolloid Therapy: Further Observations and Comparisons with Radiocolloids of P-32, Dy-165, and Y-90", Intemational Joumal of Radiation Oncology and Biological Physics, 10, 341.

Boll, A. R. and Mirzadeh, S., (1997) "Optimizations of Radiolabeling of Immuno-proteins with ${ }^{213} \mathrm{Bi}$." Proceedings of Symposium on Radiochemistry and Radioimmunotherapy, 212th ACS National Meeting, Orlando, FI, Aug. 24-28, 1996, Radiochimica Acta (in press).

Hartmann, F., Horak, E. M., Garmestani, K., Wu, C., Brechbiel, M. W., Kozak, R. W., Tso, J., Kosteiny, S. A., Gansow, O. A., Nelson, D. L. and Waldmann, T. A., (1994) "Radioimmuno-therapy of Nude Mice Bearing a Human Interleukin 2 Receptor a-expressing Lymphoma Utilizing the $a$ emitting Radionuclide-conjugated Monoclonal Antibody ${ }^{212}$ Bi-anti-Tac", Cancer Research, 54, 4362.

Hassfjell, S. P. and Hoff, P. (1994), Apply. Radiat. Isot., 45, 1021.

Huneke R. B., Pippin C. G., Squire R. A., Brechbiel, M. W., Gansow, O. A., Strand, M., (1992) "Effective Alpha-particle-mediated Radioimmunotherapy of Murine Leukemia", Cancer Res., 52, 5818.

Hursh, J. B. and Lovaas, A. I. (1967), J. Inorg. Nucl. Chem., $29,599$.

Junghans, R. P., Dobbs, D., Raubitschek, A. A., Brechbiel, M. W., Mirzadeh, S., Gansow, O. A. and Waldmann, T. A., (1993) "Pharmacokinetics and Bioactivity of DOTA-Bismuth Conjugated Anti-Tac Antibody for Alpha Emitter Therapy", Cancer Research, 53, 5683.

Kennel, S. J. and Mirzadeh, S. (1997), "Vascular Targeting for Radioimmunotherapy with ${ }^{213} \mathrm{Bi}^{\prime \prime}$. Proceedings of Symposium on Radiochemistry and Radioimmunotherapy, 212th ACS National Meeting, Orlando, FI, Aug. 24-28, 1996, Radiochimica Acta (in press).

Lambrecht, R. M. (1983) "Radionuclide generator", Radiochim. Acta, 34, 9.

Lambrecht, R. M. and Mirzadeh, S. (1985) "Cyclotron Isotopes and Radiopharmaceuticals, XXXV. Astatine-211," International Journal of Applied Radiation and Isotopes, 36, 443.

Mani, R. S. (1987) "Reactor Prodcution of Radionuclides for Generators", Radiochim Acta, 41, 103.

Meyer, G.-J. and Lambrecht, R. M. (1980) "Excitation Function for the ${ }^{209} \mathrm{Bi}\left({ }^{7} \mathrm{Li}, 5 \mathrm{n}\right){ }^{211} \mathrm{Rn}$ Nuclear Reaction", Int. J. Appl. Radiat. Isot., 31, 351.

Mirzadeh, S. and Lambrecht, R. M., (1987) "Method for Simultaneous Preparation of Rn-211, Xe125, Xe-123, At-211 and I-125", U.S. Patent 4,664,869, May 12, 1987. 
Mirzadeh, S. and Lambrect, R. M. (1987) "Procedure for Producing At-211 for Radiopharmaceutical Use", U.S. Patent 4,681,727, Jul. 21, 1987.

Mirzadeh, S., Schenter, R. E., Callahan, A. P. and Knapp, F. F., Jr. (1992) Production Capabilities in U. S. Nuclear Reactors for Medical Radioisotopes, ORNLTM-12010.

Mirzadeh, S. Kumar, K. and Gansow, O. A. (1993) "The Chemical Fate of ${ }^{212}$ Bi-DOTA Formed by B-Decay of ${ }^{212} \mathrm{~Pb}(\mathrm{DOTA})^{2-}$ Complex", Radiochimica Acta, 60,1.

Norman, J. H., Wrasidlo, W. A., and Mysels, K. J. (1991), U.S. Patent 5,038,046, 1991.

Ruegg, C. L., W. T. Anderson-Berg, M. W. Brechbiel, S. Mirzadeh, O. A. Gansow and M. Strand, (1990) "Improved in vivo Stability and Tumor Targeting of Bismuth-Labeled Antibody", Cancer Research 50, 4221.

Ruth, T. J., Dombsky, M., D'Auria, J. M., and Ward, T. E., (1988), "Radiochemistry of Astatine", Nuclear Science Series, Radiochemistry of Elements, U.S. DOE, NAS-NS-3064.

Scheinberg, D. A., (1997) "Alpha Particle Therapy for Cancer", Symposium on Radioisotopes in Medicine: New Promise for the Treatment of Cancer, Seattle, WA, Feb. 15, 1997.

Sitnikov, V. T., Norseev, Yu, and Khalkin, V., (1996) "Generator of Actinium-225", J. Radioanal. Nucl. Chem., Articles, 205, 75.

Visser, J, Brinkman, A. B., and Bakker, N. M., (1979) "Production of As and Rn Isotopes by Photospallation of ${ }^{232} \mathrm{Th}$ and ${ }^{238} \mathrm{U}$ ", Int. J. Appl. Radiat. Isot., 30, 745.

Zucchini, G. L. and Friedman, A. M. (1982) Int. J. Nucl. Med. Biol., 9, 83. 


\section{Figure Captions}

Figure 1. (a) Decay chain of ${ }^{228} \mathrm{Th}$ (Thorium Series), (b) Decay chain of ${ }^{229} \mathrm{Th}$ (Neptunium Series), and (c) Decay chain of ${ }^{227}$ Th (Actinium Series). Minor branches are not shown.

Figure 2. Reactor production of ${ }^{227} \mathrm{Ac},{ }^{228} \mathrm{Th}$ and ${ }^{229} \mathrm{Th}$ from ${ }^{226} \mathrm{Ra}$ target.

Figure 3. Theoretical production yields of ${ }^{227} \mathrm{Ac},{ }^{228} \mathrm{Th}$ and ${ }^{229} \mathrm{Th}$ from $1 \mathrm{~g}$ of ${ }^{226} \mathrm{Ra}$ as a function of irradiation time at a neutron flux of $1 \times 10^{15} \mathrm{n} \cdot \mathrm{s}^{-1} \cdot \mathrm{cm}^{-2}$, (th/epi=10). 
Table 1. Generator-Produced Alpha-emitters

\begin{tabular}{ll}
\hline Parent/daughter pair & Reference \\
\hline${ }^{211} \mathrm{Rn}(14.6 \mathrm{~h}) \rightarrow{ }^{211} \mathrm{At}(7.2 \mathrm{~h})$ & $\begin{array}{l}\text { Mirzadeh and Lambrecht (1987), } \\
\text { Meyer and Lambrecht (1980), } \\
\text { Visser et al. (1979). }\end{array}$ \\
${ }^{224} \mathrm{Ra}(3.7 \mathrm{~d}) \rightarrow{ }^{212} \mathrm{~Pb}(10 \mathrm{~h}) \rightarrow{ }^{212} \mathrm{Bi}(60 \mathrm{~m})$ & $\begin{array}{l}\text { Atcher et al. (1987), } \\
\text { Hassfjell and Hoff (1994) } \\
\text { Zucchini and Friedman (1982), }\end{array}$ \\
${ }^{225} \mathrm{Ra}(14.8) \rightarrow{ }^{225} \mathrm{Ac}(10.0 \mathrm{~d}) \rightarrow{ }^{213} \mathrm{Bi}(45.6 \mathrm{~m})$ & $\begin{array}{l}\text { Boll and Mirzadeh (1997), } \\
\text { Sitnikov et al. (1996) }\end{array}$ \\
${ }^{227} \mathrm{Th}(18.7 \mathrm{~d}) \rightarrow{ }^{223} \mathrm{Ra}(11.4 \mathrm{~h})$ & $\begin{array}{l}\text { Mani, 1987 } \\
{ }^{255} \mathrm{Es}(40 \mathrm{~d}) \rightarrow{ }^{255} \mathrm{Fm}(20.1 \mathrm{~h})\end{array}$ \\
\end{tabular}

9 
Table 2. Decay properties of radionuclides with potential use in alpha-particle-mediated radioimmunotherapy

\begin{tabular}{|c|c|c|c|c|c|}
\hline $\begin{array}{l}\text { Radio- } \\
\text { nuclide }\end{array}$ & $\begin{array}{l}\text { Half- } \\
\text { life }\end{array}$ & $\begin{array}{l}\text { Decay } \\
\text { mode }(\%)^{a}\end{array}$ & $\begin{array}{l}\text { Decay } \\
\text { prodcut }\end{array}$ & $\begin{array}{c}\text { Av. } \mathrm{E}_{a} \text { or } \mathrm{E}_{\beta}^{\mathrm{b}} \\
(\mathrm{keV})\end{array}$ & $\begin{array}{l}E_{y}\left(I_{y}\right) \\
(\mathrm{keV})(\%)^{\mathrm{c}}\end{array}$ \\
\hline $\begin{array}{l}{ }^{211} \mathrm{At} \\
{ }^{211} \mathrm{Po}\end{array}$ & $\begin{array}{c}7.2 \mathrm{~h} \\
516 \mathrm{~ms}\end{array}$ & $\begin{array}{l}E C(58.3) \\
a(41.7) \\
a\end{array}$ & $\begin{array}{l}516-\mathrm{ms}{ }^{211} \mathrm{Po} \\
30.7-\mathrm{y}{ }^{207} \mathrm{Bi} \\
\text { stable }{ }^{207} \mathrm{~Pb}\end{array}$ & $\begin{array}{l}- \\
2447 \\
7443\end{array}$ & $\begin{array}{l}76.9(13) \\
79.3(22)\end{array}$ \\
\hline $\begin{array}{l}{ }^{212} \mathrm{Bi} \\
{ }^{212} \mathrm{Po} \\
{ }^{208} \mathrm{Tl}\end{array}$ & $\begin{array}{l}60.6 \mathrm{~m} \\
298 \mathrm{~ns} \\
3.05 \mathrm{~m}\end{array}$ & $\begin{array}{l}B(64.1) \\
a(35.9) \\
a \\
B\end{array}$ & $\begin{array}{l}298-n s{ }^{212} \mathrm{Po} \\
3.05-\mathrm{m}^{208} \mathrm{~T} \\
\text { stable }{ }^{208} \mathrm{~Pb} \\
\text { stable }{ }^{208} \mathrm{~Pb}\end{array}$ & $\begin{array}{c}492 \\
2174 \\
8784 \\
560\end{array}$ & $\begin{array}{l}727(6.3) \\
- \\
583(86) \\
2615(100)\end{array}$ \\
\hline $\begin{array}{c}{ }^{213} \mathrm{Bi} \\
{ }^{213} \mathrm{Po} \\
{ }^{209} \mathrm{TI}\end{array}$ & $\begin{array}{l}45.6 \mathrm{~m} \\
4.2 \mu \mathrm{s} \\
2.2 \mathrm{~m}\end{array}$ & $\begin{array}{l}B(97.8) \\
a(2.16) \\
a \\
B\end{array}$ & $\begin{array}{l}4.2-\mu s^{213} \mathrm{Po} \\
2.2-\mathrm{m}^{209} \mathrm{~T} \\
3.3-\mathrm{h}^{209} \mathrm{~Pb} \\
3.3-\mathrm{h}^{209} \mathrm{~Pb}\end{array}$ & $\begin{array}{c}444 \\
5869 \\
8375 \\
659\end{array}$ & $\begin{array}{l}440(26) \\
- \\
- \\
117(81) \\
467(81) \\
566(98) \\
-\end{array}$ \\
\hline $\begin{array}{l}{ }^{223} \mathrm{Ra} \\
{ }^{219} \mathrm{Rn}\end{array}$ & $\begin{array}{l}11.4 \mathrm{~d} \\
3.96 \mathrm{~s}\end{array}$ & $\begin{array}{l}a \\
a\end{array}$ & $\begin{array}{l}{ }^{4-s^{219}}{ }^{\mathrm{Rn}} \\
1.8-\mathrm{ms}^{215} \mathrm{Po}\end{array}$ & $\begin{array}{l}5697 \\
6812\end{array}$ & $\begin{array}{l}269(14) \\
271(10) \\
402(6.6)\end{array}$ \\
\hline $\begin{array}{l}{ }^{215} \mathrm{Po} \\
{ }^{211} \mathrm{~Pb}\end{array}$ & $\begin{array}{l}1.78 \mathrm{~ms} \\
36.1 \mathrm{~m}\end{array}$ & $\begin{array}{l}a \\
B\end{array}$ & $\begin{array}{l}36-\mathrm{m}^{211} \mathrm{~Pb} \\
2.1-\mathrm{m}^{211} \mathrm{Bi}\end{array}$ & $\begin{array}{c}7386 \\
447\end{array}$ & $\begin{array}{l}405(3.5) \\
832(3.1)\end{array}$ \\
\hline $\begin{array}{l}{ }^{211} \mathrm{Bi} \\
{ }^{211} \mathrm{Po} \\
{ }^{207} \mathrm{TI}\end{array}$ & $\begin{array}{l}516 \mathrm{~ms} \\
4.8 \mathrm{~m}\end{array}$ & $\begin{array}{l}B(0.27) \\
a(99.7) \\
a \\
B\end{array}$ & $\begin{array}{l}516-\mathrm{ms}^{211} \mathrm{Po} \\
4.8-\mathrm{m}{ }^{207} \mathrm{~T} \\
\text { stable }{ }^{207} \mathrm{~Pb} \\
\text { stable }{ }^{207} \mathrm{~Pb}\end{array}$ & $\begin{array}{r}0.5 \\
6550 \\
7443 \\
493\end{array}$ & 351 (13) \\
\hline${ }^{255} \mathrm{Fm}$ & $20.1 \mathrm{~h}$ & $a$ & $898-d{ }^{251} \mathrm{Cf}$ & 7091 & $81.5(0.01)$ \\
\hline
\end{tabular}

a When not indicated, branching is $100 \%$.

${ }^{b}<E_{B}>=\left(A v . E_{B} \cdot I_{B}\right) / \Sigma I_{B},<E_{a}>=\left(E_{\alpha} \cdot I_{a}\right) / \Sigma I_{\alpha}$.

Number of emission per 100 decay. 
Table 3. Nuclear Reaction for Production of ${ }^{211}$ At

Nuclear

Reaction
Incident particle

energy
References

Lambrecht and Mirzadeh (1985)

Mirzadeh and Lambrecht (1987)

$\sigma_{\max }=1 \mathrm{~b} @ \mathrm{E}_{\mathrm{a}}=29 \mathrm{MeV}$

Yield $=-1.5 \mathrm{mCi} / \mu \mathrm{A} @ 1 / 2$ sat.

$38 \mathrm{MeV} \leq \mathrm{E}_{\mathrm{Li}} \leq 60 \mathrm{MeV}$

$\sigma_{\max }=0.7 \mathrm{~b} @ \mathrm{E}_{\mathrm{Li}}=54 \mathrm{MeV}$

Meyer and Lambrecht

${ }^{209} \mathrm{Bi}\left[{ }^{6} \mathrm{Li}, 4 \mathrm{n}\right]{ }^{211} \mathrm{Rn} \rightarrow{ }^{211} \mathrm{At}$

Yield $=-2 \mu \mathrm{Ci} / \mathrm{nA} @ 1 / 2$ sat.

$$
\begin{aligned}
{ }^{232} \mathrm{Th}[\mathrm{p}, \mathrm{spall}]{ }^{211} \mathrm{Rn} \rightarrow{ }^{211} \mathrm{At} & \mathrm{E}_{\mathrm{p}} \geq 200 \mathrm{MeV} \\
& \sigma=0.7 \mathrm{mb} @ \mathrm{E}_{\mathrm{p}}=28 \mathrm{GeV}
\end{aligned}
$$

${ }^{232} \mathrm{Th}[y$, spall $]{ }^{211} \mathrm{Rn} \rightarrow{ }^{211} \mathrm{At} \quad \sigma=0.13 \mathrm{mb} @ \mathrm{E}_{\gamma}=300 \mathrm{MeV}$
Mirzadeh and Lambrecht (1987)

Visser et al. (1979) 
Table 4. ${ }^{225} \mathrm{Ac} /{ }^{213} \mathrm{Bi}$ Generator $-{ }^{213} \mathrm{Bi}$ Yield, ${ }^{225} \mathrm{AC}$ and ${ }^{225} \mathrm{Ra}$ Breakthrough

\begin{tabular}{|c|c|c|c|c|c|c|c|c|}
\hline \multirow{2}{*}{\multicolumn{2}{|c|}{ Elution }} & \multirow{2}{*}{\multicolumn{2}{|c|}{$\begin{array}{l}{ }^{213} \mathrm{Bi} \\
\text { Yield }\end{array}$}} & \multicolumn{4}{|c|}{ Breakthrough } & \multirow{3}{*}{$\mathrm{Ra} / \mathrm{Ac}$} \\
\hline & & & & \multicolumn{2}{|c|}{${ }^{225} \mathrm{AC}$} & \multicolumn{2}{|c|}{${ }^{225} \mathrm{Ra}$} & \\
\hline No. & Days & $(\mu \mathrm{Ci})$ & (\%) & $(\mu \mathrm{C} i)$ & (\%) & $(\mu \mathrm{Ci})$ & (\%) & \\
\hline 1 & 3 & 650 & 96 & $4.3 \times 10^{-3}$ & $6.4 \times 10^{-4}$ & $2.8 \times 10^{-3}$ & $2.9 \times 10^{-1}$ & 453 \\
\hline 6 & 4 & 615 & 98 & $6.7 \times 10^{-3}$ & $1.1 \times 10^{-3}$ & $1.2 \times 10^{-3}$ & $1.3 \times 10^{-1}$ & 118 \\
\hline 15 & 10 & 400 & 97 & $2.9 \times 10^{-2}$ & $7.5 \times 10^{-3}$ & $1.5 \times 10^{-3}$ & $2.3 \times 10^{-1}$ & 31 \\
\hline 19 & 12 & 351 & 97 & $2.9 \times 10^{-1}$ & $8.6 \times 10^{-2}$ & $1.4 \times 10^{-3}$ & $2.4 \times 10^{-1}$ & 2.8 \\
\hline 23 & 13 & 325 & 96 & $6.0 \times 10^{-2}$ & $1.9 \times 10^{-2}$ & $1.3 \times 10^{-3}$ & $2.3 \times 10^{-1}$ & 12 \\
\hline 28 & 18 & 218 & 91 & $1.3 \times 10^{-2}$ & $5.6 \times 10^{-3}$ & $1.3 \times 10^{-3}$ & $2.7 \times 10^{-1}$ & 52 \\
\hline
\end{tabular}

Column: $\quad \sim 2 \times 15 \mathrm{~mm} \sim 200 \mathrm{mg}$ of $\mathrm{AG} 50 \mathrm{~W}-\mathrm{X} 4$ resin

Load: $\quad 830 \mu \mathrm{Ci}{ }^{225} \mathrm{Ac}$ and $1.1 \mu \mathrm{Ci}^{225} \mathrm{Ra}$ in $100 \mu \mathrm{L}$ of $0.03 \mathrm{M} \mathrm{HNO}_{3}$

Eluent: $\quad 200 \mu \mathrm{L}$ of $0.15 \underline{\mathrm{M}} \mathrm{HI}$, Flow rate: $\sim 0.5 \mathrm{~mL} / \mathrm{min}$ 

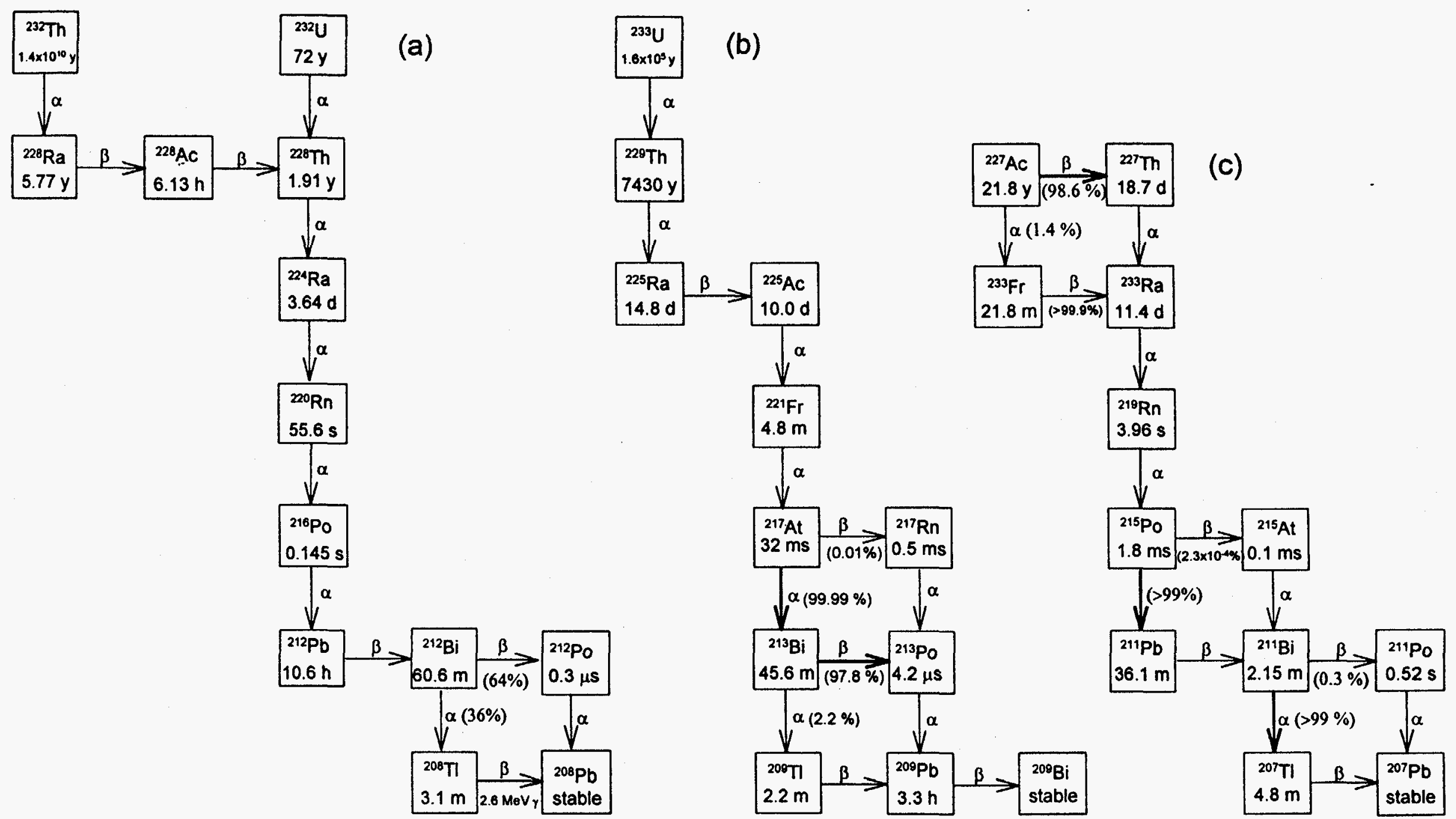


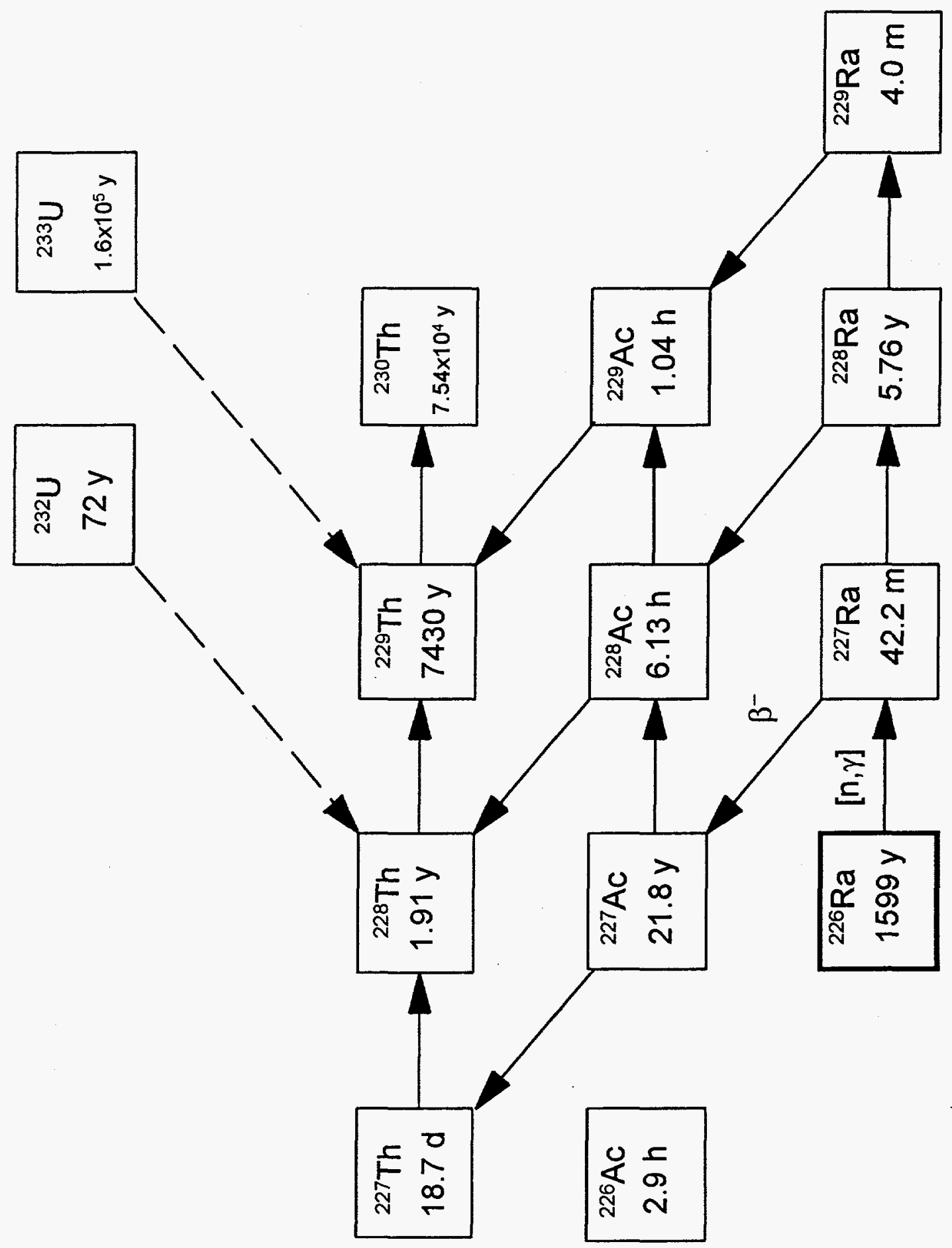

$$
\text { 눈 }
$$




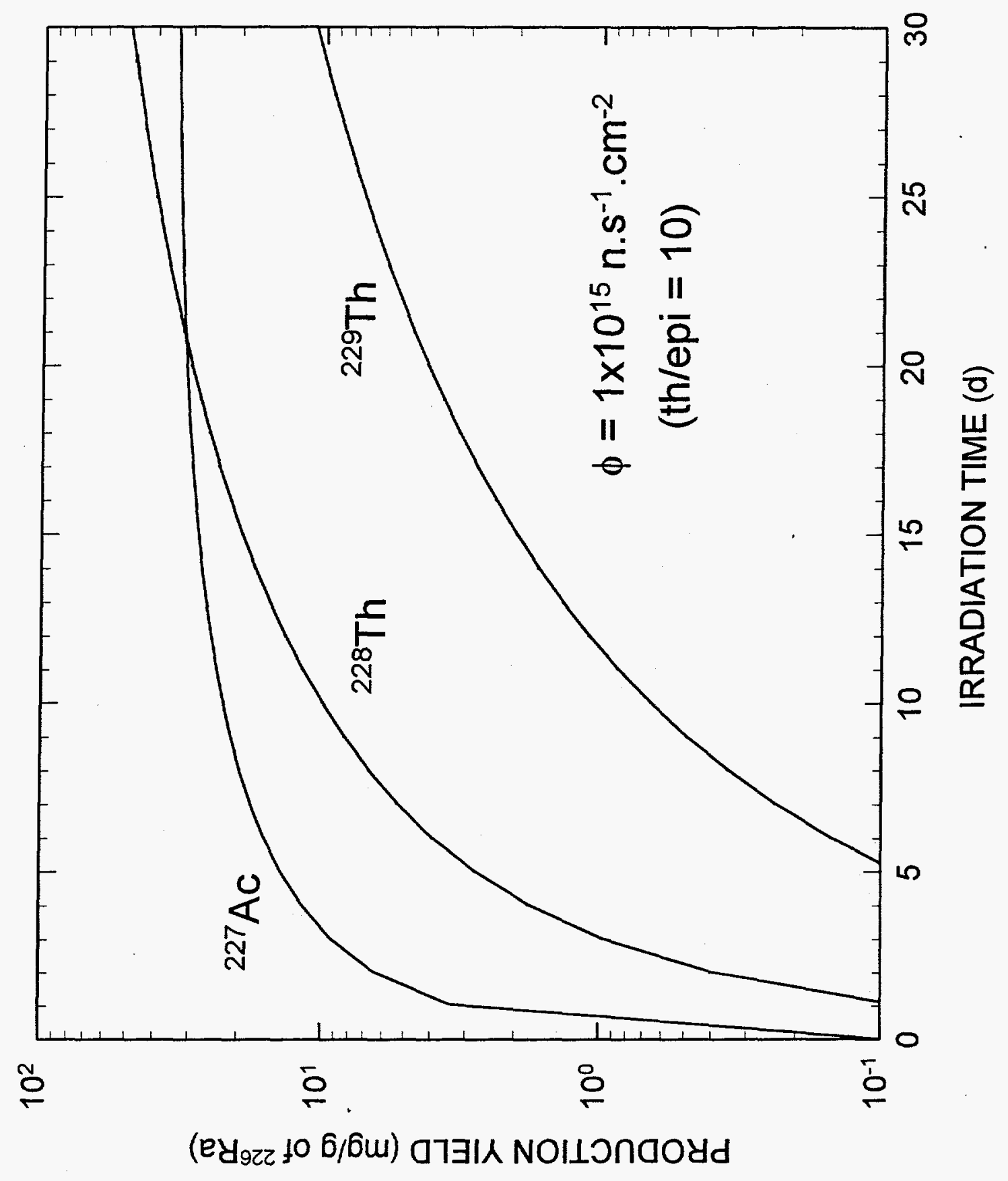

